\title{
Pien Tze Huang inhibits the growth of hepatocellular carcinoma cells by upregulating miR-16 expression
}

\author{
FEI QI ${ }^{1,2^{*}}$, SONGQIANG ZHOU ${ }^{3 *}, \mathrm{LI} \mathrm{LI}^{4}$, LIHUI WEI ${ }^{1,2}$, \\ ALING SHEN $^{1}$, LIYA LIU ${ }^{1}$, YAODONG WANG ${ }^{3}$ and JUN PENG ${ }^{1,2}$ \\ ${ }^{1}$ Academy of Integrative Medicine; ${ }^{2}$ Fujian Key Laboratory of Integrative Medicine on Geriatrics, Fujian University of \\ Traditional Chinese Medicine, Fuzhou, Fujian 350122; Departments of ${ }^{3}$ Hepatobiliary Surgery and ${ }^{4}$ Disease Prevention \\ and Healthcare, Fujian Provincial Hospital, Fujian Medical University, Fuzhou, Fujian 350001, P.R. China
}

Received May 21, 2017; Accepted August 23, 2017

DOI: $10.3892 / \mathrm{ol} .2017 .7240$

\begin{abstract}
Hepatocellular carcinoma (HCC) is characterized by uncontrolled proliferation and the deregulation of apoptotic signaling, although its molecular pathogenesis is not fully characterized. The ability to inhibit excessive proliferation and induce the apoptosis of cancer cells are crucial characteristics of anticancer drugs. Pien Tze Huang (PZH) is a widely used traditional Chinese medicine for the treatment of various types of cancer, and has exhibited promising therapeutic effects in clinical trials of HCC. However, the underlying mechanisms for its action are unclear. In the present study, the aim was to explore the effect of $\mathrm{PZH}$ on the proliferation and apoptosis of the BEL-7402 HCC cell line, and the associated mechanisms. PZH treatment significantly inhibited BEL-7402 cell viability, confluence and clonogenicity, inducing cell cycle arrest and promoting apoptosis. In addition, $\mathrm{PZH}$ treatment suppressed the expression of the pro-proliferative genes cyclin D1 and cyclin-dependent kinase 4 , and decreased the expression of the anti-apoptotic gene Bcl-2. PZH treatment also upregulated the expression of a key microRNA (miR), miR-16. The study demonstrated that PZH can effectively inhibit cancer cell
\end{abstract}

Correspondence to: Dr Yaodong Wang, Department of Hepatobiliary Surgery, Fujian Provincial Hospital, Fujian Medical University, 134 Dongjie, Fuzhou, Fujian 350001, P.R. China

E-mail: wangyaodongch@163.com

Dr Jun Peng, Academy of Integrative Medicine, Fujian University of Traditional Chinese Medicine, 1 Qiuyang Road, Shangjie, Minhou, Fuzhou, Fujian 350122, P.R. China

E-mail: pjunlab@hotmail.com

*Contributed equally

Abbreviations: HCC, hepatocellular carcinoma; PZH, Pien Tze Huang; TCM, traditional Chinese medicine

Key words: Pien Tze Huang, hepatocellular carcinoma, proliferation, apoptosis, microRNA-16 proliferation and induce apoptosis in BEL-7402 HCC cells via the upregulation of the tumor suppressor miR-16.

\section{Introduction}

Hepatocellular carcinoma (HCC) is one of the leading causes for cancer-associated mortality, with one of the fastest-rising morbidity and mortality rates worldwide (1-3). Although surgical resection, systemic chemotherapy and targeted cancer therapy are widely used, the response to therapy and prognosis of patients with HCC remain suboptimal due to the development of drug resistance and severe adverse side effects (4-8). Therefore, it is essential to explore and develop novel strategies for the control and treatment of HCC.

Cancer cells are characterized by uncontrolled proliferation and the deregulation of apoptotic signaling (9). Cell proliferation is primarily regulated by cell cycle checkpoints. One of the major cell cycle checkpoints is the G1/S checkpoint; G1/S progression is regulated by the pro-proliferative cyclin D1/cyclin-dependent kinase (CDK)4 complex $(10,11)$. The expression of cyclin D1 and CDK4 are often upregulated in various types of cancer (12-14). Bcl-2 serves a critical role in inhibiting apoptosis and is overexpressed in numerous types of cancer (15-18). The ability to inhibit excessive proliferation and induce the apoptosis of cancer cells is paramount in the development of anticancer drugs.

MicroRNAs (miRNAs/miRs) are a class of endogenous short noncoding RNAs that primarily suppress gene expression by specifically binding to the 3'-untranslated region of target mRNAs (19-21). A single miRNA can modulate the expression of hundreds of different targets and may therefore be implicated in a broad range of physiological and pathological processes $(22,23)$. It has been demonstrated that miRNAs may function as oncogenes or tumor suppressors to modulate multiple oncogenic cellular processes, including cell proliferation, apoptosis, invasion and metastasis (24-26). miR-16 is localized at chromosome $13 q 14.3$, and is downregulated in the majority of patients with chronic lymphocytic leukemia (CLL) (27) and HCC (28). It has been reported that the upregulation of miR-16 inhibits cell proliferation, induces cell cycle arrest and increases the rate of apoptosis by downregulating the expression of $\mathrm{Bcl}-2$ in $\mathrm{CLL}$, colorectal cancer 
and HCC $(29,30)$. It has also been demonstrated that miR-16 may inhibit tumor cell proliferation by targeting cyclin D1 and CDK4 to induce cell cycle arrest (31-33).

Traditional Chinese medicine (TCM) has been used in China for thousands of years and may provide treatment with multi-target and multi-level intervention against various types of cancer, with relatively few side effects $(34,35)$. Pien Tze Huang $(\mathrm{PZH})$, a well-known TCM formula that originated in the Chinese Ming Dynasty $>450$ years ago, has been widely used in China and Southeast Asia as a remedy for various diseases, including cancer (36). It was previously demonstrated that PZH may inhibit colon cancer growth via multiple mechanisms (37-49) and $\mathrm{PZH}$ has exhibited promising therapeutic effects in clinical trials regarding $\operatorname{HCC}(50,51)$. However, the effect of PZH on HCC, including on miR-16 expression level, has not been evaluated; therefore, the present study aimed to explore the effect of $\mathrm{PZH}$ on the proliferation and apoptosis of the HCC BEL-7402 cell line.

\section{Materials and methods}

Materials and reagents. RPMI-1640 medium, fetal bovine serum (FBS), penicillin, streptomycin and trypsin-EDTA were purchased from Thermo Fisher Scientific, Inc. (Waltham, MA, USA). A Hoechst staining kit was purchased from the Beyotime Institute of Biotechnology (Shanghai, China). A BD Pharmingen ${ }^{\mathrm{TM}}$ Cell Cycle kit was obtained from BD Biosciences (San Jose, CA, USA). An RNAiso Plus for Total RNA kit, an RNAiso for microRNA kit, a PrimeScript ${ }^{\mathrm{TM}}$ RT reagent kit and a $S Y B R^{\circledR}$ PrimeScript $^{\mathrm{TM}}$ miRNA RT-PCR kit were purchased from Takara Biotechnology Co., Ltd. (Dalian, China). SYBR ${ }^{\circledR}$ Select Master Mix was purchased from Thermo Fisher Scientific, Inc. Antibodies against CDK4 (cat no. 2906S), cyclin D1 (cat no. 2978S), Bcl-2 (cat no. 15071S) and $\beta$-actin (cat no. 4967S), horseradish peroxidase (HRP)-conjugated goat anti-rabbit immunoglobulin ( $\mathrm{Ig}$ )G, (cat no. 7074P2) and HRP-conjugated horse anti-mouse IgG (cat no. 7076S) were obtained from Cell Signaling Technology, Inc. (Beverly, MA, USA).

Preparation of $\mathrm{PZH}$. PZH was obtained from and authenticated by Zhangzhou Pien Tze Huang Pharmaceutical Co., Ltd. (Zhangzhou, China; Chinese Food and Drug Administration approval no. Z35020242). PZH was prepared by dissolving in PBS to a stock concentration of $20 \mathrm{mg} / \mathrm{ml}$, which was stored at $-20^{\circ} \mathrm{C}$. Dissolving the stock solution in RPMI-1640 to varying concentrations produced the working concentrations of $\mathrm{PZH}$.

Cell culture. Human HCC BEL-7402 cells were purchased from the Cell Bank of the Chinese Academy of Sciences (Shanghai, China). Cells were cultured in RPMI-1640 medium containing $10 \%$ (v/v) FBS, $100 \mathrm{U} / \mathrm{ml}$ penicillin and $100 \mu \mathrm{g} / \mathrm{ml}$ streptomycin, and maintained in a humidified incubator at $37^{\circ} \mathrm{C}$ with $5 \% \mathrm{CO}_{2}$.

Evaluation of cell viability by MTT assay. Cell viability was assessed by an MTT assay. BEL-7402 cells were seeded in 96-well plates at a density of $8 \times 10^{3}$ cells/well in $100 \mu \mathrm{l}$ medium. Cells were incubated overnight and treated with various concentrations $(0,0.25,0.5$ and $0.75 \mathrm{mg} / \mathrm{ml})$ of $\mathrm{PZH}$ for 24 ,
48 or 72 h. An MTT assay was subsequently performed by the addition of $100 \mu \mathrm{l}$ MTT reagent (Beijing Solarbio Science \& Technology Co., Ltd., Beijing, China) and $0.5 \mathrm{mg} / \mathrm{ml}$ PBS into each well, followed by incubation for $4 \mathrm{~h}$ at $37^{\circ} \mathrm{C}$. The resulting purple-blue MTT formazan precipitate was dissolved in $100 \mu \mathrm{l}$ DMSO. The optical density (OD) at $570 \mathrm{~nm}$ was measured with an ELISA reader (ELX800; BioTek Instruments, Inc., Winooski, VT, USA). Cell viability was determined using the following formula: Cell viability $=$ (absorbance of the experimental samples/absorbance of the control samples) x100\%.

Observation of cell confluence. BEL-7402 cells were seeded into 6-well plates at a density of $2.5 \times 10^{5}$ cells/well and treated with $0,0.25,0.5$ or $0.75 \mathrm{mg} / \mathrm{ml} \mathrm{PZH}$ for $24 \mathrm{~h}$. Cell confluence was observed using a phase-contrast microscope (Leica Microsystems GmbH, Wetzlar, Germany). Images were captured at x200 magnification.

Cell cycle analysis. Cell cycle analysis was performed by flow cytometry using a FACSCalibur system (Becton-Dickinson, San Jose, CA, USA). Following treatment with $0,0.25,0.5$ or $0.75 \mathrm{mg} / \mathrm{ml} \mathrm{PZH}$ for $24 \mathrm{~h}, \mathrm{BEL}-7402$ cells were collected at a final concentration of $1 \times 10^{6}$ cells $/ \mathrm{ml}$, then fixed in $70 \%$ ethanol at $4^{\circ} \mathrm{C}$ overnight. The cells were subsequently washed twice with ice cold PBS and incubated with propidium iodide $(10 \mu \mathrm{g} / \mathrm{ml})$ and a BD Pharmingen ${ }^{\mathrm{TM}}$ Cell Cycle kit, which contained DNase ( $8 \mu \mathrm{g} / \mathrm{ml}$; BD Biosciences) for $30 \mathrm{~min}$. The fluorescence signal was observed in the FL2 channel and the proportion of DNA in each phase was analyzed using Modfit LT software version 3.0 (Verity Software House, Inc., Topsham, ME, USA).

Colony formation assay. BEL-7402 cells were seeded into 6 -well plates at a density of $2.5 \times 10^{5}$ cells/well and treated with $0,0.25,0.5$ or $0.75 \mathrm{mg} / \mathrm{ml} \mathrm{PZH} \mathrm{for} 24 \mathrm{~h}$. The cells were subsequently reseeded into 6-well plates in RPMI-1640 without $\mathrm{PZH}$ at a density of $1 \times 10^{3}$ cells/well. Following incubation for 8 days, cell colonies were fixed with $4 \%$ paraformaldehyde for $10 \mathrm{~min}$ at room temperature, stained with $0.1 \%$ crystal violet for $15 \mathrm{~min}$ at room temperature and observed using phase-contrast microscopy. The number of colonies per plate were counted.

Detection of apoptosis with Hoechst staining. BEL-7402 cells were seeded into 12 -well plates at a density of $1 \times 10^{5}$ cells/well, and treated with $0,0.25,0.5$ or $0.75 \mathrm{mg} / \mathrm{ml} \mathrm{PZH} \mathrm{for} 24 \mathrm{~h}$. Cells were subsequently washed with $\mathrm{PBS}$, fixed with $4 \%$ polyoxymethylene for $10 \mathrm{~min}$ at room temperature and washed twice more in PBS. Cells were then incubated in Hoechst 33258 for $10 \mathrm{~min}$ in the dark at $37^{\circ} \mathrm{C}$ and observed using a phase-contrast fluorescence microscope (Leica Microsystems $\mathrm{GmbH}$ ). Images were captured at x200 magnification.

$R N A$ extraction and reverse transcription-quantitative polymerase chain reaction (RT-qPCR) analysis. BEL-7402 cells were seeded into 6 -well plates at a density of $2.5 \times 10^{5}$ cells/well in $2 \mathrm{ml}$ medium. The cells were treated with $0,0.25,0.5$ or $0.75 \mathrm{mg} / \mathrm{ml} \mathrm{PZH} \mathrm{for} 24 \mathrm{~h}$.

Analysis of Bcl-2, CDK4 and cyclin Dl expression. Total RNA was isolated with RNAiso Plus reagent, and $1 \mu \mathrm{g}$ of total RNA 
was reverse-transcribed with the PrimeScript ${ }^{\mathrm{TM}} \mathrm{RT}$ reagent kit according to the manufacturer's protocol. The produced cDNA was used to determine the mRNA expression of Bcl-2, CDK4 and cyclin D1 by qPCR with the SYBR ${ }^{\circledR}$ Select Master Mix using the ABI 7500 Fast instrument (both from Thermo Fisher Scientific, Inc.) under the following thermocycling conditions: $50^{\circ} \mathrm{C}$ for $2 \mathrm{~min}, 95^{\circ} \mathrm{C}$ for $2 \mathrm{~min}$ and 40 cycles at $95^{\circ} \mathrm{C}$ for $1 \mathrm{sec}$ and $60^{\circ} \mathrm{C}$ for $30 \mathrm{sec}$. GAPDH was used as an internal control. Primer sequences are listed in Table I.

Analysis of miR-16 expression. Total miRNA was isolated with the RNAiso for microRNA kit. Total miRNA $(1 \mu \mathrm{g})$ was reverse-transcribed with the $S \mathrm{SBR}^{\circledR}{ }^{\circledR}$ PrimeScript $^{\mathrm{TM}}$ miRNA RT-PCR kit according to the manufacturer's protocol. The resulting cDNA was used to determine the expression of miR-16 by qPCR; U6 was used as an internal control. The primers for U6 (cat no. D356-03) and miR-16 (cat no. DHM0135) were obtained from Takara Biotechnology Co., Ltd. qPCR was performed with the $\mathrm{SYBR}^{\circledR}$ Premix Ex Taq II using the ABI 7500 Fast instrument under the following thermocycling conditions: $95^{\circ} \mathrm{C}$ for $30 \mathrm{sec}, 40$ cycles at $95^{\circ} \mathrm{C}$ for $5 \mathrm{sec}$ and $60^{\circ} \mathrm{C}$ for $30 \mathrm{sec}$.

Quantification of $q P C R$ results. The mRNA or miRNA expression levels were determined as $\Delta \mathrm{Cq}=\mathrm{Cq}$ (sample) $-\mathrm{Cq}$ (U6 or GAPDH) and relative quantities between different samples were determined as $\Delta \Delta \mathrm{Cq}=\Delta \mathrm{Cq}$ (sample 1) $-\Delta \mathrm{Cq}$ (sample 2); values were expressed as $2^{-\Delta \Delta C q}$. All qPCR reactions were conducted in triplicate.

Western blot analysis. BEL-7402 cells were seeded into $25 \mathrm{~cm}^{2}$ culture flasks at a density of $2.5 \times 10^{5}$ cells $/ \mathrm{ml}$ and treated with $0,0.25,0.5$ or $0.75 \mathrm{mg} / \mathrm{ml} \mathrm{PZH}$ for $24 \mathrm{~h}$. Cells were lysed with cell lysis buffer (CWBIO, Beijing, China) containing protease and phosphatase inhibitor cocktails, and the resulting total protein concentration was determined by a bicinchoninic acid assay. Proteins (50 $\mu \mathrm{g} /$ lane) were resolved on $10 \%$ SDS-PAGE gels and electroblotted onto polyvinyl difluoride membranes. The membranes were blocked for $1 \mathrm{~h}$ at room temperature with blocking buffer (Beyotime Institute of Biotechnology) and probed with primary antibodies for Bcl-2, CDK4, cyclin D1 and $\beta$-actin (dilution, $1: 1,000$ ) overnight at $4^{\circ} \mathrm{C}$, then incubated with an appropriate HRP-conjugated secondary antibody for $1 \mathrm{~h}$ at room temperature (dilution, 1:5,000). Protein bands were subsequently detected using Thermo Scientific ${ }^{\mathrm{TM}}$ SuperSignal ${ }^{\mathrm{TM}}$ West Pico Chemiluminescent Substrate (Thermo Fisher Scientific, Inc.).

Statistical analysis. Statistical analysis was performed using one-way analysis of variance with Bonferroni's multiple comparison test using SPSS 18.0 software (SPSS, Inc., Chicago, IL, USA). Data were presented as the mean of three individual experiments. $\mathrm{P}<0.05$ was considered to indicate a statistically significant difference.

\section{Results}

PZH inhibits the proliferation of BEL-7402 cells. The effect of PZH on the proliferation of BEL-7402 cells was evaluated using phase-contrast microscopy. PZH treatment
Table I. Polymerase chain reaction primer sequences.

\begin{tabular}{ll}
\hline Gene & \multicolumn{1}{c}{ Primers (5' to 3') } \\
\hline Bcl-2 & F: CAGCTGCACCTGACGCCCTT \\
& R: GCCTCCGTTATCCTGGATCC \\
Cyclin D1 & F:TGGATGCTGGAGGTCTGCGAGGAA \\
& R: GGCTTCGATCTGCTCCTGGCAGGC \\
Cyclin-4 & F: CATGTAGACCAGGACCTAAGC \\
dependent kinase & R: AACTGGCGCATC AGATCCTAG \\
GAPDH & F: CGACCACTTTGTCAAGCTCA \\
& R: AGGGGTCTACATGGCAACTG \\
\hline
\end{tabular}

F, forward; R, reverse.

decreased the confluence and cell density of BEL-7402 cells in a dose-dependent manner (Fig. 1A). Furthermore, the MTT assays demonstrated that PZH treatment significantly decreased the cell viability of BEL-7402 cells in a dose- and time-dependent manner (Fig. 1B; $\mathrm{P}<0.05$ ). In addition, a colony formation assay indicated that $\mathrm{PZH}$ treatment significantly reduced the clonogenicity rate of BEL-7402 cells (Fig. 1C; $\mathrm{P}<0.05)$.

PZH inhibits G1/S transition in BEL-7402 cells. Cell cycle analysis was then performed using flow cytometry. There was a significant increase in the number of BEL-7402 cells in G0/G1 phase following treatment with $0.75 \mathrm{mg} / \mathrm{ml} \mathrm{PZH}$, whereas the percentage of cells in $\mathrm{S}$ phase was decreased, compared with untreated control cells (Fig. 2; $\mathrm{P}<0.05$ ).

PZH induces the apoptosis of BEL-7402 cells. The rate of BEL-7402 cell apoptosis following PZH treatment was determined using Hoechst staining. PZH-treated cells exhibited the typical morphological features of apoptosis, including chromatin condensation and nuclear fragmentation, at a greater rate compared with the untreated control cells, which exhibited more homogenous staining of the nuclei (Fig. 3).

PZH modulates the expression of Bcl-2, cyclin D1, CDK4 and miR-16 in BEL-7402 cells. In order to determine the underlying mechanisms for the pro-apoptotic and anti-proliferative activity of PZH, the expression of key factors associated with cell cycle regulation and apoptosis was examined using RT-qPCR and western blot analysis. As demonstrated in Fig. 4A, miR-16 expression was significantly upregulated following treatment with $\mathrm{PZH}$ in a dose-dependent manner $(\mathrm{P}<0.05)$. In addition, PZH treatment decreased the mRNA (Fig. 4A; $\mathrm{P}<0.05$ for doses $\geq 0.5 \mathrm{mg} / \mathrm{ml}$ ) and protein expression levels (Fig. 4B) of Bcl-2, cyclin D1 and CDK4.

\section{Discussion}

$\mathrm{HCC}$ is one of the leading causes of cancer-associated mortality worldwide (1-3). Current treatment strategies for HCC include surgery, chemotherapy and targeted drug therapy (4-7). However, there are significant limitations in the effectiveness of current treatment options due to the development of drug 
A
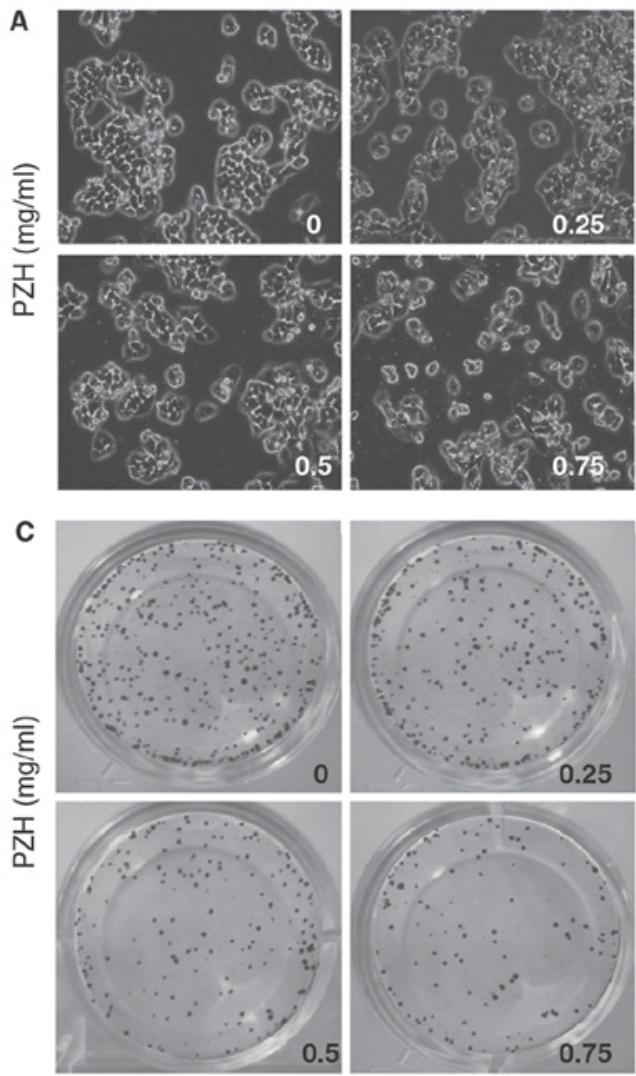

B
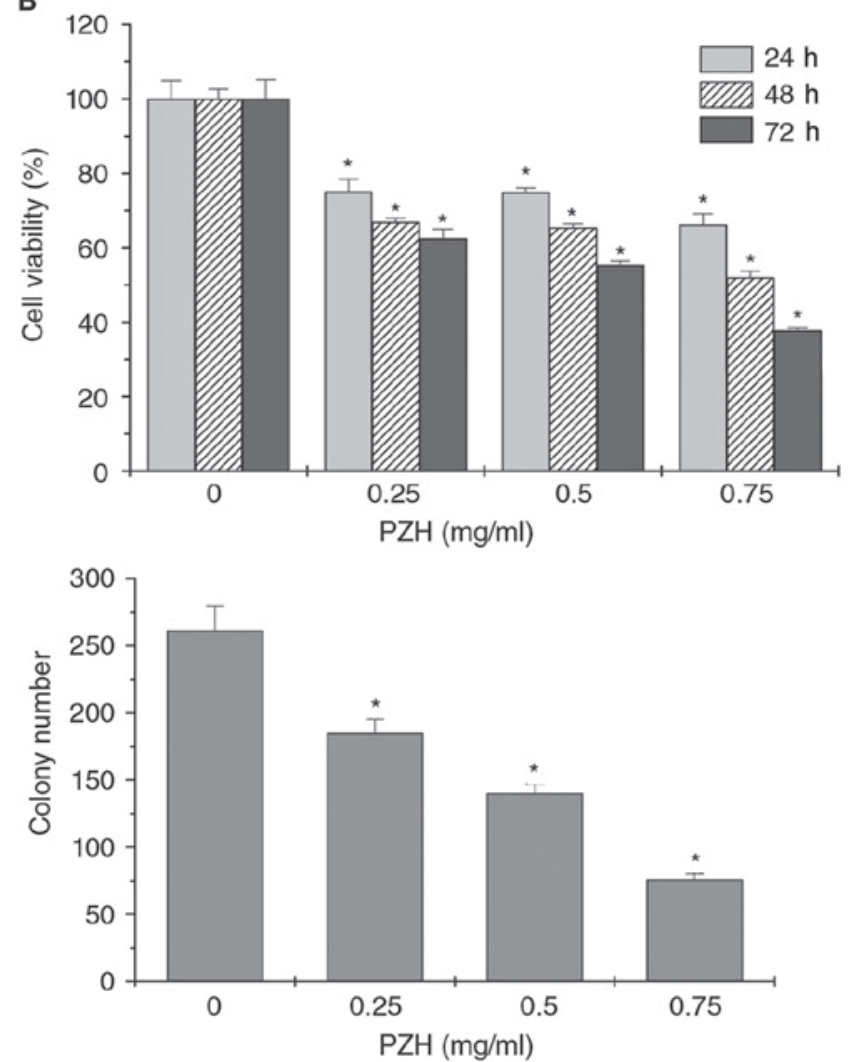

Figure 1. Effect of PZH on the proliferation of BEL-7402 cells. (A) Representative images of the confluence of BEL-7402 cells as observed using phase-contrast microscopy. Magnification, x200. (B) Relative viability of BEL-7402 cells, as determined using MTT assays. (C) Cell clonogenicity as determined by a colony formation assay, with representative images. Data are represented as the mean \pm standard deviation from 3 independent experiments. ${ }^{*} \mathrm{P}<0.05$ vs. respective control group. PZH, Pien Tze Huang.

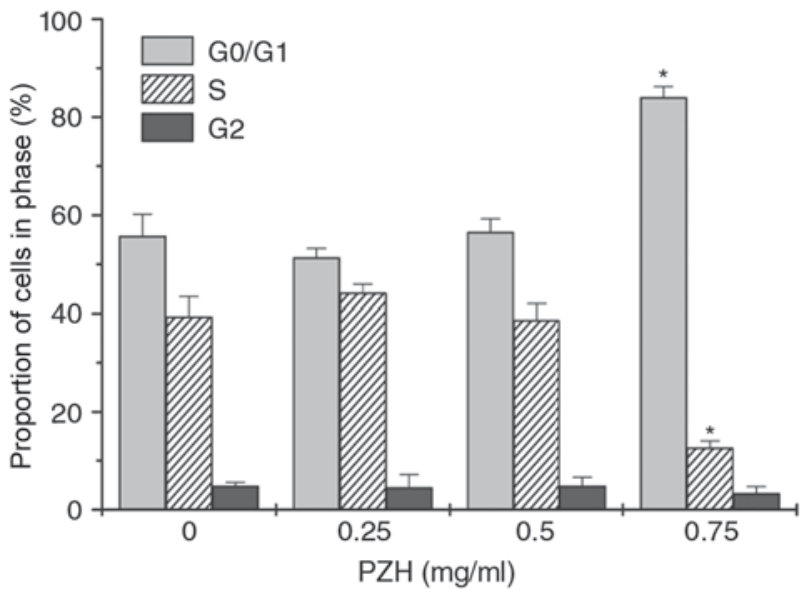

Figure 2. Effect of PZH on the cell cycle distribution of BEL-7402 cells. Following treatment with $\mathrm{PZH}$, cells were stained with propidium iodide and analyzed by flow cytometry. The proportion of DNA in the G0/1, S and G2 phases was calculated using Modfit LT software. Data are represented as the mean \pm standard deviation from 3 independent experiments. ${ }^{*} \mathrm{P}<0.05$ vs. respective control group. PZH, Pien Tze Huang.

resistance and non-specific cytotoxicity. The TCM treatment of cancer has received widespread attention due to its therapeutic efficacy and relatively few side effects. Previous studies have demonstrated that the commonly used TCM formula PZH can inhibit the growth and metastasis of colorectal cancer
$\mathrm{PZH}(\mathrm{mg} / \mathrm{ml})$
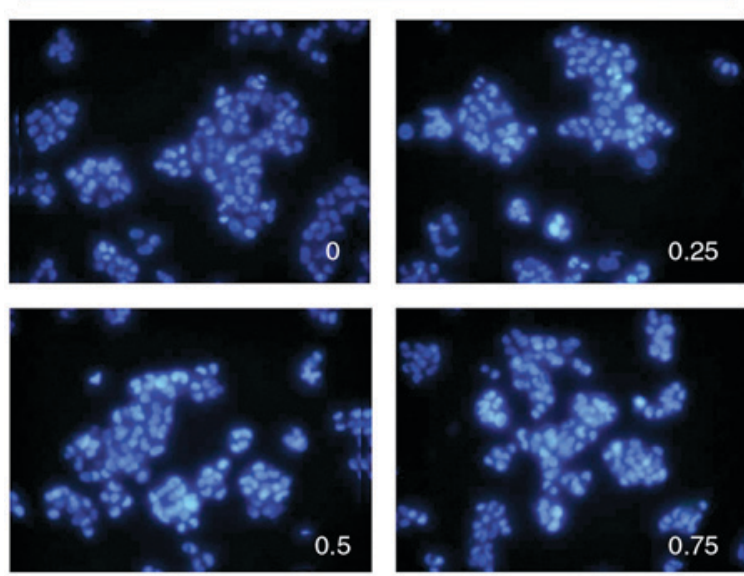

Figure 3. Effect of PZH on the apoptosis of BEL-7402 cells. The extent of apoptosis was evaluated with Hoechst staining. Stained images were recorded using a phase-contrast fluorescence microscope. Images are representative of 3 independent experiments. Magnification, x200. PZH, Pien Tze Huang.

cells (34-46). However, its effects on HCC and the underlying mechanisms remain unclear.

miRNAs may serve crucial functions in liver tumorigenesis by regulating various proliferation and apoptosis-associated pathways. Previous studies have reported that miR-16 upregulation inhibited cell proliferation and induced cell 


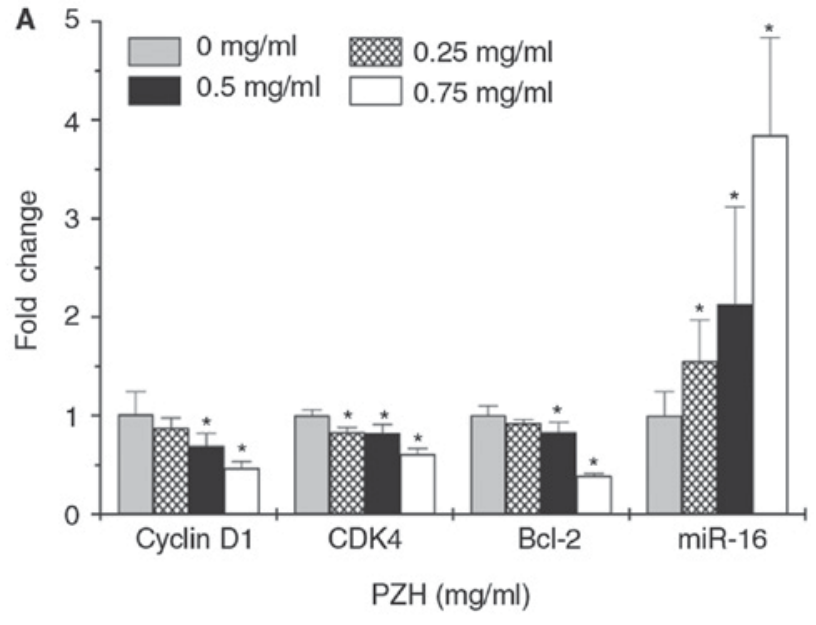

B

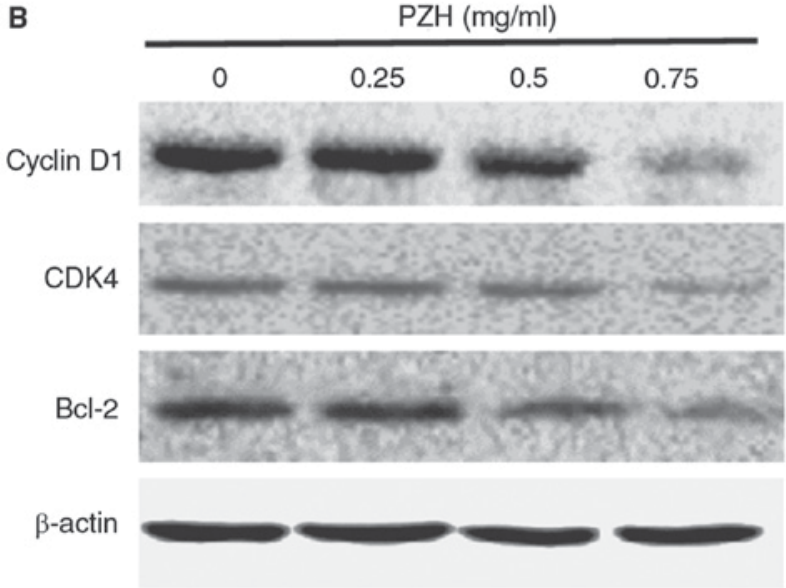

Figure 4. Effect of PZH on the expression of proliferation and apoptosis-associated genes in BEL-7402 cells. (A) The mRNA expression levels of cyclin D1, CDK4, Bcl-2 and miR-16 in BEL-7402 cells were analyzed by reverse transcription-quantitative polymerase chain reaction. GAPDH and U6 were used as the internal control for mRNA and miRNA, respectively. Data are represented as mean \pm standard deviation from $\geq 3$ independent experiments. ${ }^{*} \mathrm{P}<0.05$ vs. control group. (B) The protein expression levels of cyclin D1, CDK4 and Bcl-2 in BEL-7402 were analyzed by western blotting. $\beta$-actin was used as the internal control. Images are representatives of three independent experiments. PZH, Pien Tze Huang; CDK4, cyclin-dependent kinase 4; miR/miRNA, microRNA.

cycle arrest $(29,30)$. Thus, determining the effect of miRNAs, particularly miR-16, in HCC and the effect of PZH treatment on miR-16 expression may be of critical importance. The aim of the present study, was to demonstrate the inhibitory effect of PZH treatment on the proliferation and apoptosis of the BEL-7402 HCC cell line and explore the underlying mechanisms. It was identified that $\mathrm{PZH}$ treatment significantly decreased the viability and survival of BEL-7402 cells in a dose- and time-dependent manner. In addition, higher doses of $\mathrm{PZH}$ increased the percentage of cells in the G0/G1 phase and prevented G1/S cell cycle progression. Consistent with these data, PZH treatment significantly downregulated the expression of the anti-apoptotic gene $\mathrm{Bcl}-2$, and the pro-proliferative factors cyclin D1 and CDK4. In addition, the miR-16 expression level in BEL-7402 cells was significantly upregulated following PZH treatment.

To conclude, the data of the present study demonstrate that PZH suppresses HCC growth through inhibiting cancer cell proliferation and inducing apoptosis. Modulating the expression of miR-16 and its target genes may be a possible mechanism for PZH's anti-tumor action.

\section{Acknowledgements}

The present study was sponsored by the National Natural Science Foundation of China (grant no. 81673721), the Joint Project of the Education and Health Bureaus of Fujian Province (grant no. WKJ-FJ-21) and the Research Fund of the Education Bureau of Fujian Province (grant no. JA14162).

\section{References}

1. Howlader N, Noone AM, Krapcho M, Garshell J, Neyman N, Altekruse SF, Kosary CL, Yu M, Ruhl J, Tatalovich Z, et al (eds): SEER cancer statistics review, 1975-2010. Natl Cancer Inst, Bethesda, MD, USA, 2013.

2. Simard EP, Ward EM, Siegel R and Jemal A: Cancers with increasing incidence trends in the United States: 1999 through 2008. CA Cancer J Clin 62: 118-128, 2012.

3. Siegel R, Ma JM, Zou ZH and Jemal A: Cancer Statistics, 2014. CA Cancer J Clin 64: 9-29, 2014.

4. Lin S, Hoffmann K and Schemmer P: Treatment of hepatocellular carcinoma: A systematic review. Liver Cancer 1: 144-158, 2012.

5. Forner A, Llovet JM and Bruix J: Hepatocellular carcinoma. Lancet 379: 1245-1255, 2012.

6. Lu SC: Where are we in the chemoprevention of hepatocellar carcinoma? Hepatology 51: 734-736, 2010.

7. Villanueva A and Llovet JM: Targeted therapies for hepatocellular carcinoma. Gastroenterol 140: 1410-1426, 2011.

8. Darvesh AS, Aggarwal BB and Bishayee A: Curcumin and liver cancer: A review. Curr Pharm Biotechnol 13: 218-228, 2012.

9. Evan GI and Vousden KH: Proliferation, cell cycle and apoptosis in cancer. Nature 411: 342-348, 2001.

10. Nurse P: Ordering S phase and $M$ phase in the cell cycle. Cell 79: 547-550, 1994.

11. Morgan DO: Principles of CDK regulation. Nature 374: 131-134, 1995.

12. Haraken S, Abu-EI-Ardat K, Diab-Assaf M, Niedzwiecki A, EI-Sabban M and Rath M: Epigallocatechin-3-gallate induces apoptosis and cell cycle arrest in HTLV-1-positive and -negative leukemia cells. Med Oncol 25: 30-39, 2008.

13. Purohit A, Hejaz HA, Walden L, MacCarthy-Morrogh L, Packham G, Potter BVL and Reed MJ: The effect of 2-methoxyoestrone-3-O-sulphamate on the growth of breast cancer cells and induced mammary tumors. Int $\mathrm{J}$ Cancer 85: 584-589, 2000.

14. Kessel D and Luo Y: Cells in cryptophycin-induced cell-cyclearrest are susceptible to apoptosis. Cancer Lett 151: 25-29, 2000.

15. Adams JM and Cory S: The Bcl-2 apoptotic switch in cancer development and therapy. Oncogene 26: 1324-1337, 2007.

16. Cory S and Adams JM: The Bcl-2 family: Regulators of the cellular life-of-death switch. Nat Rev Cancer 2: 647-656, 2002.

17. Peng J, Ding J, Tan C, Baggenstoss B, Zhang Z, Lapolla SM and Lin J: Oligomerization of membrane-bound Bcl-2 is involved in its pore formation induced by tBid. Apoptosis 14: 1145-1153, 2009.

18. Peng J, Tan C, Roberts GJ, Nikolaeva O, Zhang Z, Lapolla SM, Primorac S, Andrews DW and Lin J: tBID elicits a conformational alteration in membrane-bound Bcl-2 such that it inhibits Bax pore formation. J Biol Chem 281: 35802-35811, 2006.

19. Valencia-Sachez MA, Liu J, Hannon GJ and Parker R: Control of translation and mRNA degradation by miRNAs and siRNAs. Genes Dev 20: 515-524, 2006.

20. Bagga S and Pasquinelli AE: Identification and analysis of microRNAs. Genet Eng (NY) 27: 1-20, 2006.

21. Bar N and Dikstein R: miR-22 forms a regulatory loop in PTEN/AKT pathway and modulates signaling kinetics. PLoS One 5: e10859, 2010.

22. Guo H, Ingolia NT, Weissman JS and Bartel DP: Mammalian microRNAs predominantly act to decrease target mRNA levels. Nature 466: 835-840, 2010.

23. Bartel DP: MicroRNA: Target recognition and regulatory function. Cell 136: 215-233, 2009 
24. Leskelä S, Leandro-García LJ, Mendiola M, Barriuso J, Inglada-Pérez L, Muñoz I, Martínez-Delgado B, Redondo A, de Santiago J, Robledo M, et al: The mir-200 family controls beta-tubulin III expression and is associated with paclitaxel-based treatment response and progression-free survival in ovarian cancer patients. Endocr Relat Cancer 18: 85-95, 2011.

25. Uhlmann S, Zhang J, Schwäger A, Mannsperger H, Riazalhosseini Y, Burmester S, Ward A, Korf U, Wiemann S and Sahin Ö: miR-200bc/429 cluster targets PLCgammal and differentially regulates proliferation and EGF-driven invasion than miR-200a/141 in breast cancer. Oncogene 29: 4297-4306, 2010.

26. Li H, Tang J, Lei H, Cai P, Zhu H, Li B, Xu X, Xia Y and Tang W: Decreased miR-200a/141 suppress cell migration and proliferation by targeting PTEN in Hirschsprung's disease. Cell Physiol Biochem 34: 543-553, 2014

27. Calin GA, Dumitru CD, Shimizu M, Bichi R, Zupo S, Noch E, Aldler H, Rattan S, Keating M, Rai K, et al: Frequent deletions and down-regulation of micro-RNA genes miR15 and miR16 at 3 q14 in chronic lymphocytic leukemia. Proc Natl Acad Sci USA 99: 15524-15529, 2002.

28. Huang YH, Lin KH, Chen HC, Chang ML, Hsu CW, Lai MW, Chen TC, Lee WC, Tseng YH and Yeh CT: Identification of postoperative prognostic microRNA predictors in hepatocellular carcinoma. PLoS One 7: e37188, 2012.

29. Cimmino A, Calin GA, Fabbri M, lorio MV, Ferracin M, Shimizu M, Wojcik SE, Ageilan RI, Zupo S, Dono M, et al: miR-15 and miR-16 induce apoptosis by targeting BCL2. Proc Natl Acad Sci USA 102: 13944-13949, 2005.

30. Tsang WP and Kwok TT: Epigallocatechin gallate up-regulation of miR-16 and induction of apoptosis in human cancer cells J Nutr Biochem 21: 140-146, 2010.

31. Jiang Q, Zhang Y, Zhao M, Li Q, Chen R, Long X, Fang W and Liu Z: miR-16 induction after CDK4 knockdown is mediated by c-Myc suppression and inhibits cell growth as well as sensitizes nasopharyngeal carcinoma cells to chemotherapy. Tumour Biol 37: 2425-2433, 2016.

32. Pekarsky Y and Croce CM: Role of miR-15/16 in CLL. Cell Death Differ 22: 6-11, 2015.

33. Cai CK, Zhao GY, Tian LY, Liu L, Yan K, Ma YL, Ji ZW, Li XX, Han K, Gao J, et al: miR-15a and miR-16-1 downregulate CCND1 and induce apoptosis and cell cycle arrest in osteosarcoma. Oncol Rep 28: 1764-1770, 2012.

34. Gordaliza M: Natural products as leads to anticancer drugs. Clin Transl Oncol 9: 767-776, 2007.

35. Ji HF, Li XJ and Zhang HY: Natural products and drug discovery. Can thousands of years of ancient medical knowledge lead us to new and powerful drug combination in the fight against cancer and dementia? EMBO Rep 10: 194-200, 2009.

36. Chinese pharmacopoeia commission, pharmacopoeia of the Peoples Repubic of Chian, Beijing. Chinese medical science and technology press, pp263, 2010.

37. Lin JM, Wei LH, Chen YQ, Liu XX, Hong ZF, Sferra TJ and Peng J: Pien Tze Huang induced apoptosis in human colon cancer HT-29 cells is associated with regulation of the Bcl-2 family and activation of caspase 3. Chin J Integr Med 17: 685-690, 2011.

38. Zhuang Q, Hong F, Shen A, Zheng L, Zeng J, Lin W, Chen Y, Sferra TJ, Hong Z and Peng J: Pien Tze Huang inhibits tumor cell proliferation and promotes apoptosis via suppressing the STAT3 pathway in colorectal cancer mouse. Int J Oncol 40: 1569-1574, 2012.
39. Shen AL, Hong F, Liu LY, Lin JM, Zhuang QC, Hong ZF and Peng J: Effects of Pien Tze Huang on angiogenesis in vivo and in vitro. Chin J Integr Med 18: 431-436, 2012.

40. Shen A, Hong F, Liu L, Lin J, Wei L, Cai Q, Hong Z and Peng J: Pien Tze Huang inhibits the proliferation of human colon carcinoma cells by arresting G1/S cell cycle progression. Oncol Lett 4: 767-770, 2012.

41. Shen A, Chen Y, Hong F, Lin J, Wei L, Hong Z, Sferra TJ and Peng J: Pien Tze Huang suppresses IL-6-inducible STAT3 activation in human colon carcinoma cells through induction of SOCS3. Oncol Rep 28: 2125-2130, 2012.

42. Shen A, Lin J, Chen Y, Lin W, Liu L, Hong Z, Sferra TJ and Peng J: Pien Tze Huang inhibits tumor angiogenesis in a mouse model of colorectal cancer via suppression of multiple cellular pathways. Oncol Rep 30: 1701-1706, 2013.

43. Chen H, Shen A, Zhang Y, Chen Y, Lin J, Lin W, Sferra T and Peng J: Pien Tze Huang inhibits hypoxia-induced epithelial-mesenchymal transition in human colon carcinoma cells through suppression of the HIF-1 pathway. Exp Ther Med 7: 1237-1242, 2014

44. Shen A, Chen H, Chen Y, Lin J, Lin W, Liu L, Sferra TJ and Peng J: Pien Tze Huang overcomes multidrug resistance and epithelial-mesenchymal transition in human colorectal carcinoma cells via suppression of TGF- $\beta$ pathway. Evid Based Complement Alternat Med 2014: 679436, 2014.

45. Chen H, Feng J, Zhang Y, Shen A, Chen Y, Lin J, Lin W, Sferra TJ and Peng J: Pien Tze Huang inhibits hypoxia-induced angiogenesis via HIF-1a/VEGF-A pathway in colorectal cancer. Evid-Based Complement Alternat Med 2015: 454279, 2015.

46. Shen A, Lin W, Chen Y, Liu L, Chen H, Zhuang Q, Lin J, Sferra TJ and Peng J: Pien Tze Huang inhibits metastasis of human colorectal carcinoma cells via modulation of TGF- $\beta 1 / \mathrm{ZEB} / \mathrm{miR}-200$ signaling network. Int J Oncol 46: 685-690, 2015

47. Wei L, Chen P, Chen Y, Shen A, Chen H, Lin W, Hong Z, Sferra TJ and Peng J: Pien Tze Huang suppresses the stem-like side population in colorectal cancer cells. Mol Med Rep 9: 261-266, 2014.

48. Qi F, Wei L, Shen A, Chen Y, Lin J, Chu J, Cai Q, Pan J and Peng J: Pien Tze Huang inhibits the proliferation, and induces the apoptosis and differentiation of colorectal cancer stem cells via suppression of the Notch1 pathway. Oncol Rep 35: 511-517, 2016.

49. Lin J, Feng J, Jin Y, Yan Z, Lai Z and Peng J: Pien Tze Huang suppresses VEGF-C-mediated lymphangiogenesis in colorectal cancer. Oncol Rep 36: 3568-3576, 2016.

50. Xu YY and Yu EX: Clinical analysis of the analysis of the effect of Pien Tze Huang in treatment of 42 patients with moderate or advanced liver cancer. Shanghai J Tradit Chin Med 12: 4-5, 1994.

51. Xu YY: The effect of Pien Tze Huang in treatment of liver cancer is good. Med World 11: 62, 2001. 